УДК 378.416+005.336.3

DOI https://doi.org/10.26661/2522-4360-2021-2-26

\title{
ПІДГОТОВКА МАГІСТРІВ СПЕЦІАЛЬНОСТІ «ПРОФЕСІЙНА ОСВІТА» ДО РОЗРОБКИ ЗАСОБІВ ПЕДАГОГІЧНОГО КОНТРОЛЮ
}

\author{
Шугайло Я. В. \\ кандидат педагогічних наук, \\ доиент кафедри професійної освіти в сфері технологій та дизайну \\ Киівський національний університет технологій та дизайну \\ вул. Немировича-Данченка, 2, Київ, Україна \\ orcid.org/0000-0003-4359-8164 \\ shugaylo.yv@knutd.edu.ua \\ Паращак T. I. \\ студентка I курсу магістратури \\ Київський національний університет технологій та дизайну \\ вул. Немировича-Данченка, 2, Київ, Украӥна \\ orcid.org/0000-0003-2870-8951 \\ tanuta@email.ua \\ Желізна К. О. \\ студентка I курсу магістратури \\ Київський національний університет технологій та дизайну \\ вул. Немировича-Данченка, 2, Київ, Украӥна \\ orcid.org/0000-0002-0849-2551 \\ ksenijastadnik@gmail.com
}

\author{
Ключові слова: результати \\ навчання, иілі навчання, \\ педагогічний тест, \\ вчительський тест, \\ таксономія, специифікація.
}

Стаття висвітлює досвід підготовки магістрів спеціальності 015.36 Професійна освіта (Технологія виробів легкої промисловості), що навчаються в Київському національному університеті технологій та дизайну, до розробки педагогічних тестів. Магістри професійної освіти після успішного завершення навчання мають можливість працювати викладачами спеціальних дисциплін у галузі легкої промисловості в закладах професійно-технічної освіти. Їхня майбутня професійна діяльність вимагає готовності до проведення різних видів та форм педагогічного контролю. Тестування є одним із найбільш ефективних, економічних, об'єктивних методів контролю, а тест - одним із найбільш поширених засобів (інструментів) контролю. У статті наголошено, що формування умінь та навичок розробки такого виду педагогічних тестів, як вчительські тести, може здійснюватись під час викладання дисципліни «Педагогіка та психологія вищої школи». Проаналізовано наукові пошуки, присвячені тестуванню в освітньому процесі, теорії та практиці розробки тестів. Підкреслено необхідність ознайомлення здобувачів освіти з таксономією навчальних цілей Бенджаміна Блума як 3 інструментом, що дозволяє визначити результати навчання в когнітивній сфері. Наведено приклади дієслів, що можуть використовуватись у формулюванні тестових завдань, спрямованих на різні рівні навчальних цілей. Проаналізовано алгоритм розробки тестів. Висвітлено приклад застосування таблиці специфікації, що дозволяє дотриматись вимоги функціональної валідності під час розробки педагогічного тесту. Зазначено, що результати вчительських тестів свідчать про успішність 
засвоєння навчального матеріалу здобувачами освіти та мають бути використані педагогічними працівниками для аналізу ефективності викладання, застосування використаних методів та засобів навчання, їх корекції. Наведено приклад практичного завдання для магістрів, виконання якого підвищує успішність засвоєння теоретичного матеріалу щодо розробки педагогічних тестів, сприяє формуванню умінь та навичок розробки засобів педагогічного контролю.

\title{
TRAINING OF MASTERS OF SPECIALTY VOCATIONAL EDUCATION FOR THE DEVELOPMENT OF PEDAGOGICAL CONTROL MEANS
}

\author{
Shuhailo Ya. V. \\ Candidate of Pedagogical Sciences, \\ Kyiv National University of Technologies and Design \\ Nemyrovycha-Danchenka str., 2, Kyiv, Ukraine \\ orcid.org/0000-0003-4359-8164 \\ shugaylo.yv@knutd.edu.ua \\ Parashchak T. I. \\ 1-st year Master's Student \\ Kyiv National University of Technologies and Design \\ Nemyrovycha-Danchenka str., 2, Kyiv, Ukraine \\ orcid.org/0000-0003-2870-8951 \\ tanuta@email.ua \\ Zhelizna K. O. \\ 1-st year Master's Student \\ Kyiv National University of Technologies and Design \\ Nemyrovycha-Danchenka str., 2, Kyiv, Ukraine \\ orcid.org/0000-0002-0849-2551 \\ ksenijastadnik@gmail.com
} Associate Professor at the Department of Vocational Education in Technologies and Design

Key words: learning outcomes, learning objectives, pedagogical test, teacher test, taxonomy, specification.
The article highlights the experience of masters' students of speciality 015.36 Vocational Education (Technology of light industry products), studying at the Kyiv National University of Technology and Design, training to develop pedagogical tests. Masters of vocational education after successful studying of the educational program have the opportunity to work as teachers of special disciplines in the field of light industry in vocational education institutions. Their future professional activity requires readiness to conduct various types and forms of pedagogical control. Testing is one of the most effective, economical, objective methods of control, and test is one of the most widespread means (tools) of control today. The article emphasizes that the formation of skills and abilities to develop such types of pedagogical tests as teacher-made tests can be carried out during the teaching of the discipline "Pedagogy and Psychology of Higher School". The article analyses scientific research devoted to testing in the educational process, theory and practice of test development. The necessity to acquaint students with Benjamin Bloom's taxonomy of learning goals as an effective tool to determine learning outcomes in the cognitive domain of pupils and students is emphasized. Examples of verbs that can be used to formulate test tasks targeted at different levels of learning objectives are given. The algorithm of test development is analyzed. An example of application of the specification table in the discipline "Pedagogy and Psychology of Higher School", which allows complying with the requirements of functional validity 
during the development of the pedagogical test, is given. It is noted that the results of teacher tests indicate the success of learning material mastering by students and should be used by teachers to analyze the effectiveness of teaching, teaching methods and means, to make their corrections. An example of a practical task for masters is given, the implementation of which increases the success of mastering theoretical material on the development of pedagogical tests, promotes the formation of skills and abilities to develop means of pedagogical control.

Педагогічний контроль є важливою складовою частиною освітнього процесу, оскільки він дозволяє підвищити якість підготовки майбутніх фахівців, встановити відповідність фактичних результатів навчання заявленим цілям. Він сприяє активізації навчального процесу, формуванню загальних і професійних умінь, особистісних якостей здобувачів освіти, дозволяє оцінити їхні навчальні досягнення, надати зворотній зв'язок щодо результатів навчання, виявити прогалини у знаннях, скоригувати організацію викладання, виявляти найбільш ефективні методи та засоби викладання, здійснювати аналіз ефективності діяльності педагогічного працівника тощо. Під поняттям «педагогічний контроль» ми розумітимемо виявлення, вимір і оцінку результатів навчально-пізнавальної діяльності здобувачів освіти. А як «результати навчання» розглядатимемо знання, вміння, навички, компетентності, сформовані в процесі навчання, які можна ідентифікувати, оцінити та виміряти.

Аналіз наукових джерел $[1$, с. $6 . ; 2$, с. 186; 3, с. $168 ; 4$, с. $14 ; 5$, с. 401] доводить, що педагогічне тестування $є$ одним із найбільш об'єктивних та ефективних методів педагогічного контролю, a тест $\epsilon$ найбільш поширеним засобом (в англомовних джерелах - інструментом) оцінювання результатів навчання здобувачів освіти. Тестуванню в освітньому процесі присвячені роботи низки науковців. Тестування як один із методів об'єктивізації оцінювання студентів розглянуто в роботах Д І. Назарової, С.Б. Крамар, М.В. Савочкіної, І.В. Шевченко [3]; метод оцінювання якості навчальних досягнень студентів - Г.О. Васьківської [4]. Ефективність тестування як засобу поточного контролю проаналізовано в науковому пошуку Ю.Я. Деркач, Т.В. Романів [5]. Проблема формування готовності майбутніх вчителів фізики до застосування тестових технологій досліджувалась А.В. Ткаченко, Л.О. Кулик [6]. Теорія та практика конструювання тестів висвітлена у працях Л.О. Кухар, В.П. Сергієнко [1], В.П. Головенкіна [2], I.С. Булах, М.Р. Мруги [8] та ін. Поняття тестування, процедури вимірювання та оцінювання в освіті розкрито в дослідженні Dickson A., Jephtar A. M., Dennis A. D. [9]. Використання онлайн платформ для створення тестів та опитувань висвітлено в роботі Г.А. Гордої [10]. Разом із тим проблема методичної підготовки майбутніх фахівців із професійної освіти до розробки засобів педагогічного контролю залишається недо- статньо вивченою і вимагає пошуків шляхів іiі розв'язання.

Метою статті $\epsilon$ висвітлення досвіду підготовки майбутніх фахівців із професійної освіти щодо розробки засобів педагогічного контролю під час викладання дисципліни «Психологія та педагогіка вищої школи».

Магістри професійної освіти після успішного завершення навчання можуть працювати в закладах професійно-технічної освіти викладачами спеціальних дисциплін у галузі легкої промисловості. До їхніх професійних обов'язків відноситься здійснення поточного, тематичного, проміжного, вихідного контролів знань, умінь, навичок здобувачів освіти. Зазначені види контролю дозволяють оцінити ступінь готовності здобувачів освіти до професійної діяльності на усіх етапах навчання та проінформувати стейкхолдерів про успішність засвоєння окремих компонентів освітніх програм у вигляді оцінок. Педагогічні працівники мають право самостійно обирати форми, методи поточного та тематичного контролів, а також самостійно розробляють засоби педагогічного контролю.

Нами було проведено опитування магістрів, що навчаються за освітньою програмою «Професійна освіта» (Технології виробів легкої промисловості) у Київському національному університеті технологій та дизайну щодо обізнаності з проблеми педагогічного контролю. Згідно 3 його результатами магістри мають грунтовні знання щодо його функцій, принципів, методів і форм, однак лише 1 особа 324 (4,1\% опитаних) зазначила наявність досвіду розробки педагогічних тестів, що не відповідає положенням компетентнісного підходу. Наявне протиріччя між необхідністю здійснювати педагогічний контроль у майбутній професійній діяльності, розробляти засоби педагогічного контролю та недостатньою підготовкою майбутніх фахівців із професійної освіти до цього виду діяльності зумовлює актуальність підготовки магістрів до розробки педагогічних тестів.

У наукових пошуках світових та українських вчених наводяться різні класифікації видів тестів. За критерієм «рівень упровадження» Л.О. Кухар, В.П. Сергієнко [1, с. 56] виокремлюють такі види тестів, як: національні, навчального закладу, вчительські. А. Діксон, А. М. Джефтар та А. Д. Денніс (A. Dickson, A. M. Jephtar, A. D. Dennis) [9, c. 111] виокремлюють 3 види тестів: стандартизовані тести, діагностичні тести та тести, розроблені 
вчителями (teacher-made tests). Останній вид тестів викладачі дисциплін розробляють самостійно, відповідно до навчальних програм (зміст яких швидко оновлюється), враховуючи використані ними методи і засоби навчання. Для забезпечення дотримання академічної доброчесності здобувачами освіти вони змінюються кожного навчального року. Їхніми перевагами порівняно зі стандартизованими тестами $€$ кастомізованість, можливість здійснювати конкретну, індивідуалізовану оцінку досягнень здобувачів освіти. Підготовка магістрів спеціальності 015.36 Професійна освіта (Технологія виробів легкої промисловості) до розробки таких засобів педагогічного контролю, як вчительські тести, здійснюється у процесі викладання дисципліни «Педагогіка та психологія вищої школи».

Під час вивчення дисципліни магістри ознайомлювались із видами тестів, алгоритмом розробки тесту, видами тестових завдань, правилами розробки тестових завдань викладеними в наукових пошуках $[1 ; 2,7 ; 8]$. Під час розробки тестів такого виду необхідно дотримуватись загальних рекомендацій: 1) тест має відповідати таким вимогам, як: валідність, надійність, однозначність, простота; 2) змістова валідність педагогічного тесту забезпечується повною відповідністю навчальному матеріалу (сукупність тестових завдань має бути репрезентативною вибіркою тем, що розглядались під час вивчення дисципліни); 3) функціональна валідність забезпечується відповідністю тестових завдань навчальним цілям (когнітивним рівням).

Для розробки засобів педагогічного контролю може бути використана модель визначення результатів навчання KSA(ЗУC) (Knowledge, Skills, AttitudesЗнання, Уміння, Способи мислення, погляди та цінності), які може продемонструвати здобувач освіти та які можуть бути виміряні. В англомовних наукових джерелах використовуються поняття «домен» (сфера) та визначаються результати навчання в когнітивному, психомоторному, афективному доменах. На сучасному етапі розвитку педагогіки науковцями надано рекомендації для розробки ефективних та надійних засобів контролю щодо когнітивної сфери здобувачів освіти.

Першочерговим, на нашу думку, $є$ ознайомлення студентів із таксономією навчальних цілей Бенджаміна Блума (Benjamin Bloom, 1956), що $\epsilon$ інструментарієм, який дозволяє визначити результати навчання, пересвідчитись у їх реалізації, розробляти функціонально валідні засоби педагогічного контролю. Згідно з теорією Б. Блума $[1 ; 7 ; 11 ; 12]$ ієрархія розумових процесів здобувачів освіти складається із запам'ятовування, розуміння, застосування, аналізу, синтезу та оцінки, що дозволяє виокремити шість цілей навчання у когнітивній сфері та розподілити ïx на дві групи. До першої групи (цілі нижчого порядку) відносяться: 1) знання (знання фактів та основних понять), 2) розуміння (пояснення ідей та понять), 3) використання (використання інформації в новій ситуації, виконання, впровадження). До другої групи (цілі вищого порядку) відносяться: 4) аналіз (встановлення взаємозв'язків між ідеями; диференціація; організація), 5) оцінка (обгрунтування позиції чи рішення, перевірка, критика), 6) створення (створення нової оригінальної праці; генерування, планування, виконання). Науковці П. Армстронг (Р. Armstrong) [11], О. Пометун [12] пропонують використовувати у формулюванні тестових завдань дієслова, що відповідають навчальним цілям 3 обох груп. Наприклад, для першої цілі «знання» можна використовувати дієслова «надайте визначення», «відтворіть», «перелічіть»; для другої - «поясніть», «визначте», «розташуйте», «оберіть», «зробіть переклад»; третьої - «виконайте», «застосуйте», «розв'яжіть», «зробіть малюнок, графік»; четвертої - «диференціюйте», «визначте причини / наслідки», «встановіть послідовність», «знайдіть відмінності», «зіставте», «структуруйте»; п’ятої - «спростуйте», «наведіть аргументи для підтвердження», «оберіть», «оцініть», «надайте критичний відгук», «підтримайте», «вкажіть відмінності», «обгрунтуйте»; шостої - «розробіть», «складіть», «сконструюйте», «зробіть припущення, умовивід», «сформулюйте».

У наукових пошуках визначено різні алгоритми розробки тестів. Наприклад, Л.О. Кухар, В.П. Сергієнко виокремлюють 16 універсальних етапів для розробки усіх видів тестів [1, с. 79]. Однак для розробки вчительських тестів із дисципліни ми вважаємо доцільним використання послідовності 38 етапів, запропоновані А. Діксоном, А. М. Джефтаром та А. Д. Деннісом $[9$, с. 113]. Восьмикроковий алгоритм може використовуватись як викладачами, так і студентами, оскільки не потребує грунтовної попередньої підготовки, вимагає значно меншої кількості часу. Із урахуванням поточної ситуації нами було модифіковано один з етапів, оскільки тестування проводиться 3 використанням різноманітних платформ та онлайн-сервісів. Тому майбутні фахівці із професійної освіти використовували таку послідовність: 1) визначити мету проведення тесту; 2) обрати зміст навчального матеріалу; 3) створити таблицю специфікації; 4) обрати формат та створити тестові завдання; 5) підготувати оціночний ключ; 6) написати інструкцію до тесту; 7) обрати платформу для створення тесту (Moodle, Google Форми та ін.); 8) оцінити тест.

Таблиця специфікації надає можливість визначити, що за кожною з тем дисципліни було сформульовано тестові завдання, що відповідають 6 цілям навчання (когнітивним рівням). Приклад таблиці 
специфікації в когнітивній сфері наведено в науковому пошуку А. Діксона, А. М. Джефтара та А. Д. Денніса [9]. На основі цього зразка студенти самостійно розробляли таблицю специфікації $з$ дисципліни «Педагогіка та психологія вищої школи». Приклад розподілу тестових завдань за цілями та темами (100 завдань) для дисципліни «Педагогіка та психологія вищої школи» наведено в таблиці 1.

Відмінності в кількості завдань у кожній із тем дисципліни пов'язані зі змістом навчального матеріалу, складністю його опанування, обсягом годин, що відводився на вивчення кожної з тем. Результати педагогічних тестів свідчать про успішність засвоєння здобувачами освіти навчального матеріалу. Педагогічних працівники мають здійснювати аналіз викладання матеріалу 3 тих питань/тем, що не були успішно засвоєні, вносити корективи щодо змісту, методів, засобів навчання.

Із метою формування умінь розробки засобів педагогічного контролю перед студентами ставилось завдання розробити тест тематичного контролю. Студенти самостійно обирали тему, розробляли тест, визначали критерії і розробляли шкалу оцінювання. Тест містив 18 тестових завдань (по 3 завдання для перевірки знань, умінь, навичок, способів мислення одногрупників для кожної з 6 навчальних цілей). Кожне із завдань мало містити такі елементи: 1) інструкція, 2) запитання, 3) правильна відповідь, 4) кількість балів за правильну відповідь, 5) час, відведений на виконання завдання; 6) досягнення якої з навчальних цілей діагностує завдання. Переважна частина студентів використовували для перевірки досягнення навчальних цілей нижчого порядку завдання закритого типу (1 правильний варіант відповіді та 3 дистрактори), завдання відкритого типу - для навчальних цілей вищого порядку. Виконання завдання сприяло успішності засвоєння теоретичного матеріалу щодо розробки тестів, формуванню умінь та навичок розробки вчительських тестів, спонукало магістрів до подальшої самоосвіти щодо проблеми розробки засобів педагогічного контролю.

Висновки. Магістри спеціальності 015.36 Професійна освіта (Технологія виробів легкої промисловості) в подальшій професійній діяльності здійснюватимуть основні види контролю знань, умінь, навичок здобувачів освіти, розробляти засоби, що відповідатимуть вимогам валідності, простоти, однозначності. Підготовка до розробки вчительських тестів може здійснюватись у рамках дисципліни «Педагогіка та психологія вищої школи». Для реалізації цього завдання необхідним $є$ ознайомлення магістрів із таксономією навчальних цілей Б. Блума, процедурою визначення навчальних цілей у когнітивній сфері, розробкою таблиці специфікації, алгоритмом розробки тесту, вимогами до розробки тестових завдань, Формуванню умінь та навичок сприяє самостійна розробка тематичного тесту 3 дисципліни здобувачами вищої освіти.

Подальших досліджень потребує питання вдосконалення підготовки майбутніх фахівців із професійної освіти до розробки засобів педагогічного контролю, а також проблема вибору та використання платформ та онлайн-сервісів для створення тестів.

Таблиця 1

Таблиця специфікації для розробки тесту з дисципліни «Педагогіка та психологія вищої школи»

\begin{tabular}{|c|c|c|c|c|c|c|c|}
\hline $\begin{array}{c}\text { Завдання вивчення } \\
\text { дисципліни } \\
\text { Зміст (теми) }\end{array}$ & $\begin{array}{c}\text { Знання } \\
\mathbf{( 2 0 \% )}\end{array}$ & $\begin{array}{c}\text { Розуміння } \\
\mathbf{( 2 0 \% )}\end{array}$ & $\begin{array}{c}\text { Викорис- } \\
\text { тання (15\%) }\end{array}$ & $\begin{array}{c}\text { Аналіз } \\
\mathbf{( 1 5 \% )}\end{array}$ & $\begin{array}{c}\text { Синтез } \\
\mathbf{( 1 5 \% )}\end{array}$ & $\begin{array}{c}\text { Оцінка } \\
\mathbf{( 1 5 \% )}\end{array}$ & Всього \\
\hline $\begin{array}{c}\text { Т1. ППВШ, предмет, } \\
\text { завдання, методи. }\end{array}$ & 3 & 3 & 2 & 2 & 2 & 2 & 14 \\
\hline $\begin{array}{c}\text { Т2. Освітній процес у ЗВО. } \\
\text { Зміст, форми, методи, } \\
\text { засоби навчання. }\end{array}$ & 4 & 4 & 3 & 3 & 3 & 3 & 20 \\
\hline Т3. Педагогіч-ний контроль. & 4 & 3 & 2 & 3 & 2 & 2 & 16 \\
\hline $\begin{array}{c}\text { Т4. Психологія } \\
\text { студентського віку. }\end{array}$ & 2 & 2 & 2 & 1 & 2 & 2 & 11 \\
\hline $\begin{array}{c}\text { Т5. Психологічні } \\
\text { особли-вості навчання } \\
\text { і виховання студентів. }\end{array}$ & 2 & 2 & 2 & 1 & 2 & 2 & 11 \\
\hline $\begin{array}{c}\text { Т6. Модель сучасного } \\
\text { педагога. Педагогічна } \\
\text { майстерність }\end{array}$ & 2 & 3 & 2 & 2 & 2 & 2 & 13 \\
\hline $\begin{array}{c}\text { Т7. Психологічні аспекти } \\
\text { спілкування викладачів } \\
\text { та студентів. }\end{array}$ & 3 & 3 & 2 & 3 & 2 & 2 & 15 \\
\hline усього & 20 & 20 & 15 & 15 & 15 & 15 & 100 \\
\hline
\end{tabular}




\section{ЛІТЕРАТУРА}

1. Кухар Л.О., Сергієнко В.П. Конструювання тестів: курс лекцій: навчальний посібник. Луцьк, 2010. 182 с.

2. Головенкін В.П. Педагогіка вищої школи : підручник. Київ : КПІ ім. Ігоря Сікорського, 2019. 290 с.

3. Назарова Д.І., Крамар С.Б., Савочкіна М.В., Шевченко І.В. Тестування як один з методів об'єктивізації оцінювання студентів. Украӥнський журнал медицини, біологї̈ та спорту. 2017. № 5(7). C. $167-169$.

4. Васьківська Г.О. Сутність тестування як методу оцінювання якості навчальних досягнень студентів. Актуальні проблеми підготовки сучасного педагога: теорія, історія, практика: матеріали Всеукраїнської наукової Інтернет-конференції, м. Умань, 20 жовтня 2016 р. ВПЦ «Візаві», м. Умань, Україна, С. 13-15.

5. Деркач Ю.Я., Романів Т.В. Тестування як ефективний засіб поточного контролю на уроках іноземної мови. Молодий вчений. 2018. № 9(61). С. 400-402.

6. Ткаченко А.В., Кулик Л.О. Формування готовності студентів до застосування тестових технологій важлива складова сучасної професійної підготовки майбутніх вчителів фізики. Збірник наукових пращь Кам'янеиь-Подільського наиіонального університету імені Івана Огієнка. Серія: Педагогічна. 2016. Випуск 22. С. 169-172.

7. Мудрук Сергій. Практичний посібник для розробників тестових завдань / упор. Мудрук С. URL : https://pdf.usaid.gov/pdf_docs/PA00M1CR.pdf (дата звернення: 01.08.2021).

8. Булах I.Є., Мруга М.Р. Створюємо якісний тест : навчальний посібник. Київ : Майстер-клас, 2006. $160 \mathrm{c}$.

9. Dickson A., Jephtar A. M., Dennis A. D. Test, measurement, and evaluation: understanding and use of the concepts in education. International Journal of Evaluation and Research in Education (IJERE). 2020, Vol. 9, No. 1, pp. 109-119. DOI: 10.11591/ijere.v9i1.20457.

10. Горда Г. А. Використання онлайн платформ для створення тестів та опитувань. URL : http://ict.ippo. edu.te.ua/files/files/rekomendacii/vikoristannya-onlajn-platform-dlya-stvorennya-testiv-ta-opituvan.pdf (дата звернення: 01.08.2021).

11. Armstrong, P. Bloom's Taxonomy. Vanderbilt University Center for Teaching. URL : https://cft.vanderbilt. edu/guides-sub-pages/blooms-taxonomy/ (дата звернення: 01.08.2021).

12. Пометун О. Що таке таксономія Блума і як вона працює на уроці. URL : https://www.criticalthinking. expert/usi-materialy/shho-take-taksonomiya-bluma-i-yak-vona-pratsyuye-na-urotsi/ (дата звернення: 01.08.2021).

\section{REFERENCES}

1. Kukhar L. O., Serhiienko V. P. (2010) Konstruiuvannia testiv: kurs lektsii: navchalnyi posibnyk [Construction of tests: a course of lectures: textbook]. Lutsk. $182 \mathrm{p}$.

2. Holovenkin V. P. (2019) Pedahohika vyshchoi shkoly: pidruchnyk [Higher school pedagogy: textook]. Kyiv: KPI named after Ihor Sikorskyi. 290 p.

3. Nazarova D. I., Kramar S. B., Savochkina M. V., Shevchenko I. V.(2017) Testuvannia yak odyn z metodiv ob'iektyvizatsii otsiniuvannia studentiv [Testing as one of the methods of objectification of student assessment]. Ukrainskyi zhurnal medytsyny, biolohii ta sportu [Ukrainian Journal of Medicine, Biology and Sports], 5(7), 167-169.

4. Vaskivska H. O. (2016) Sutnist testuvannia yak metodu otsiniuvannia yakosti navchalnykh dosiahnen studentiv [The essence of testing as a method of assessing the quality of academic achievements of pupils]. Aktualni problemy pidhotovky suchasnoho pedahoha: teoriia, istoriia, praktyka [Actual problems of modern teacher training: theory, history, practice:]: materials of the All-Ukrainian scientific Internet conference, Uman, Ukraine, 20 of October 2016. P. 13-15.

5. Derkach Yu. Ya., Romaniv T. V. (2018) Testuvannia yak efektyvnyi zasib potochnoho kontroliu na urokakh inozemnoi movy [Testing as an effective means of current control in foreign language lessons]. Molodyi vchenyi [Young scientist], 9(61), 400-402.

6. Tkachenko A. V., Kulyk L. O. (2016) Formuvannia hotovnosti studentiv do zastosuvannia testovykh tekhnolohii - vazhlyva skladova suchasnoi profesiinoi pidhotovky maibutnikh vchyteliv fizyky [Formation of students' readiness to use test technologies - an important component of future physics teachers modern professional training]. Zbirnyk naukovykh prats Kam'ianets-Podilskoho natsionalnoho universytetu imeni Ivana Ohiienka. Seriia: Pedahohichna [Collection of scientific works of Kamyanets-Podilsky National University named after Ivan Ogienko. Series: Pedagogical]. No. 22. P. 169-172.

7. Mudruk Serhii (2014) Praktychnyi posibnyk dlia rozrobnykiv testovykh zavdan [A practical guide for test constructors]. Retrieved [01.08.2021] from https://pdf.usaid.gov/pdf_docs/PA00M1CR.pdf 
8. Bulakh I. Ye., Mruha M. R. (2006) Stvoriuiemo yakisnyi test: navchalnyi posibnyk [Creating a quality test]. Kyiv: Master class. $160 \mathrm{p}$.

9. Dickson A., Jephtar A. M., Dennis A. D. Test, measurement, and evaluation: understanding and use of the concepts in education. International Journal of Evaluation and Research in Education (IJERE). 2020, Vol. 9, No. 1, pp. 109-119. DOI: 10.11591/ijere.v9i1.20457

10. Horda H. A. Vykorystannia onlain platform dlia stvorennia testiv ta opytuvan [The use of online platforms to create tests and surveys]. Retrieved [01.08.2021] from http://ict.ippo.edu.te.ua/files/files/rekomendacii/ vikoristannya-onlajn-platform-dlya-stvorennya-testiv-ta-opituvan.pdf

11. Armstrong, P. (2010) Bloom's Taxonomy. Vanderbilt University Center for Teaching. Retrieved [01.08.2021] from https://cft.vanderbilt.edu/guides-sub-pages/blooms-taxonomy/

12. Pometun O. Shcho take taksonomiia Bluma i yak vona pratsiuie na urotsi [What is Bloom's taxonomy and how it works in the lesson]. Retrieved [01.08.2021] from https://www.criticalthinking.expert/usimaterialy/shho-take-taksonomiya-bluma-i-yak-vona-pratsyuye-na-urotsi/ 